OPEN ACCESS

ISSN 2541-2841 (online)

ISSN 2302-6790 (print)

Edited by:

Didik Hariyanto

${ }^{*}$ Correspondence:

Nada Farah Amrudhia

amrudhiafarah@gmail

. .com

Citation:

Amrudhia, N. F., and

Nurfebiaraning, Sylvie (2021)

The "9 9 Super Shopping Day"

Advertisement Videoand Its

Impact on Shopee User on

TikTok, Kanal, 9(3).

\title{
The "9.9 Super Shopping Day" Advertisement Video and Its Impact on Shopee Users on TikTok
}

\author{
Nada Farah Amrudhia ${ }^{1 *}$, Sylvie Nurfebiaraning ${ }^{2}$ \\ 1,2 Communication and Business Faculty, Telkom University, Indonesia \\ Jl. Telekomunikasi No.1, Terusan Buahbatu-Bojongsoang, Sukapura, Kec. Dayeuhkolot, Bandung, Jawa Barat 40257
}

\begin{abstract}
The research objective of this study is to find out the influence and how much the influence of Shopee's In-Feed Native Video Ad on TikTok App toward Audience Attitude. This study focuses on Shopee's In-Feed Native Video advertising "9.9 Super Shopping Day" version on TikTok by involving one independent variable which is advertising (Variable X) measured using sub variables which are heard word, color, music, picture, seen word and movement. Dependent variable which is Audience Attitude (Variable $Y$ ) measured with cognitive,affective and conative aspect. The method used in this study is quantitative with data collection techniques through surveys to 400 respondents, which are followers of the @shopee_id account on the TikTok application. The results showed that the influence of the Advertising variable (X) on the Audience Attitude variable ( $\mathrm{Y}$ ) was $58,6 \%$. While the remaining $41,4 \%$ is influenced by other factors not examined. The t test results show that the advertising variable $(X)$ has a t value greater than the t table value because $t$ count (23.742) $>t$ table (1.96), then $\mathrm{HO}$ is rejected and $\mathrm{H} 1$ is accepted. This means that Shopee's InFeed Native Video Ad "9.9 Super Shopping Day" version on TikTok App have an impact on audience attitude.

Keywords: Ads; Ads on TikTok; Audience Attitude.
\end{abstract}

Doi:10.21070/kanal.v9i3.1227 


\section{INTRODUCTION}

Companies that focused on online-based sales, such as ecomerce, need to increase their innovation and marketing strategies aggresively, so that they can become the first choie and can attract audience to continue making purchase through their site. This is important to do because ecommerce in Indonesia are increasing, as are lifestyle and the demand for the availability of goods is more varied. Rohimah (2019) states that the presence of the online market era brings many positive sides. Promotion can be done quickly, not limitedly, accuracy and speed of service are the main needs of consumers in the era of globalization. In the digital era, business people must have partnerships with the digital era as business reform.

One of the marketing strategies of an e-commerce company is the use of online advertising. According to Rochet and Tirole in (Evans, 2009), an online advertisement is a two-sided market, where an intermediary has a platform that facilitates the relationship between consumers and advertisers. Kotler, Philip, dan Keller (2016) state that online activities and programs designed to engage customers directly or indirectly raise awareness, enhance image, or generate sales of products and services. One of the most popular advertising media used is social media. Social media is currently the most popular means of promotion and communication used because it has a very significant impact on business development. The use of social media as online advertising has been used by many e-commerce companies in Indonesia. This has the effect of increasing the number of visitors to some e-commerce companies.

One of e-commerce that use social media as their marketing strategy is Shopee. According to the Statistia report that published on https://data.tempo.co/ (Christy, 2020). Shopee is the e-commerce with the most visitor per month in the first quarter of 2020 with 71,53 million clicks. Based on www.lifepal.id, as the most visited e-commerce, Shopee certainly has some marketing strategy (Lifepal, 2020). One of the marketing strategies from Shopee is to always follow trends or things that are viral at that time. Lately, Shopee used an application which is currently viral as an advertising media, namely TikTok. TikTok is an application for mobile phones that can be downloaded on Android and iOS for free. Users can create short videos that are 15-30 seconds long. This video can be inserted with a song, audio clip, or video recording that has been previously recorded.

According to https://databoks.katadata.co.id/, in the first quarter of 2020, TikTok was the most popular and most downloaded application on the AppStore and PlayStore. It was recorded that in the first quarter, the number of TikTok downloads on the PlayStore and AppStore reached 2 billion in a short time. Over the course of 5 months, TikTok has succeeded in increasing the number of downloads by 500 million times. In Indonesia, TikTok has been downloaded m- ore than 30 million times as of June 30,2020 . This makes Indonesia ranked in the fourth place as the country with the most TikTok downloaders. TikTok's popularity has attracted companies to use this application as an advertising platform. TikTok provides 4 types of advertisements, namely Brand Takeover Ad, In-feed Native Video Ad, Hashtag Challenge Ad and Lens 2D,3D, and AR Ad. (Annur, 2020).

TikTok is a big and new application for business which offers TikTok for Business features for advertising. Even though TikTok is a new application, the fact show that TikTok is already widely used by internet users. Based on observations made by researchers, TikTok also offers different types of ads from the other apps, one of them is in-feed native video. Advertisers can make their ads as attractive as possible, and these ads will appear in users' feeds. This type of ad generally doesn't look like an ad because it looks the same as any other TikTok content. This can be used by advertisers as a strategy in advertising. In addition, the type of in feed-native video ad was chosen based on the results of pre-research conducted by researchers to 34 respondents, where shown that in-feed native video ad was the ad that most often appeared on user feeds which got $41.2 \%$, followed by hashtag challenge ads that got $32 \%$ and brand takeover ads that got $26.5 \%$.

According to Rossiter \& Percy in (Jamil, A., \& Tafifah, 2019), there are several stimuli in advertising, which are heard words, color, music, pictures, seen words, and movements. Heard words stimuli are words that are heard by the audience when an ad is shown. The words that are heard in the advertisement can make the audience understand the message that an advertisement wants to convey. Color stimuli is a combination of various color compositions used in advertisements, the lighting in ad impressions is also taken into account. Next, music stimuli is the strains of a rhythm, song, or audio in an advertisement. This musical element also accompanies an advertisement. Picture stimuli element consist of the model and the object on the ad. Seen words stimuli are words that can be seen and read by the audience during the advertisement. The last is movement stimuli. Movement stimuli is the motions seen in an advertisement. These movements should be able to influence the emotions of the audience who watched the advertisement.

Because Shopee's in-feed native video ad is an audiovisual type of advertisement, the six elements stated by Rossiter \& Percy can be found in this ad and can stimulate consumers when they view the ad. This is expected to attract potential consumers to shop on their e-commerce through their marketing communication strategies through marketing communication activity. According to Schiffman et al. (2010), marketing communication aims to achieve three stages of change. The first is, the stage of change in knowledge, when consumers know the existence of a product, for what the product was created for, and who the product is aimed at, thus the message conveyed shows no more information important of the product. 
In consumer behavior this attitude change is determined by three elements called by Schiffman et al. (2010) as tricomponent attitude changes which indicate that the stage of attitude change is determined by three components, which are cognition (knowledge), affection (feeling), and conation (behavior), if these three components indicate a tendency towards a change it is possible that an attitude change will occur. Schiffman et al. (2010) explain the cognitive component is individual information and knowledge about objects or concepts. A person's cognition is knowledge and perception obtained by the combination of direct experience with attitude-objects and related information from various sources. Affective component is an emotion or consumer feeling about a particular product or brand, while conative component is concerned with the possibility or tendency that individuals will take special actions or behave in certain ways related to the object of attitude. In marketing and consumer research, the conative component is often treated as an expression of a consumer's intention to buy or purchase decision.

In previous research conducted by Darmatama \& Erdiansyah (2021), which discusses about influence of advertising on TikTok social media on purchase decisions, shows that there is a strong and significant influence between advertisement on TikTok towards purchasing decisions on the beauty products offered. Other research conducted by Nur Ratri (2021) shows that, there is a significant and positive correlation between advertisements on video content and the hashtag \#Shopeehaul on TikTok on the consumer behavior of the millennial generation. Different to previous research that only focused on purchase decision on TikTok, this study will discuss the influence of Shopee's advertisement on audience attitudes more complexly by involving cognitive (knowledge) and affective (feeling) and conative (behaviour) component. Another difference between this research and previous research is, this research will focus on in-feed native video ads.

This research is important to conduct because based on the phenomena and data that have been described, TikTok is a big and new application that offers unique and different types of advertisements from other applications so it is necessary to conduct a study to determine the effect. This study will show whether the in-feed native video type used by Shopee to advertise can affect audience attitude or not. The components used to measure attitude in this research are cognitive (knowledge), affective (feeling), and conative (behavior).

\section{RESEARCH METHOD}

This research is included in the type of quantitative research that uses classical positivism thinking. According to Aliaga \& Gunderson (2002), quantitative research is explaining of an issue or phenomenon through gathering data in numerical form and analyzing with the aid of mathematical methods in particular statistics. Based on the purpose of this study, to de- termine the effect of advertising messages on attitudes, the type of research used in this research is descriptive research. Descriptive research is research that is used to describe, explain, and answer problems about phenomena and events happened at this time, both about the phenomenon as it is and the analysis of the relationship between various variables in a phenomenon.

The data in this study were obtained by distributing questionnaires online using google form. Respondents of this study were the follower of @ shopee_id account on TikTok Application, 19-24 years old, and have seen Shopee's in-feed native video ads "9.9 Super Shopping Day" on TikTok with a sample of 400 respondent. To categorize responses from respondents, the value of the range or interval obtained is $100 \%-25 \%=75 \%$. If the range or interval value is divided by 4 measurement scales, an interval value of $18.75 \%$ will be obtained, so that the classification of the score interpretation criteria is obtained as follows:

Tabel 1. Score Interpretation Category

\begin{tabular}{cl}
\hline \multicolumn{1}{c}{ Percentage } & Category \\
\hline $25 \%-43.75 \%$ & Very Low \\
$43.75 \%-62.50 \%$ & Low \\
$62.50 \%-81.25 \%$ & High \\
$81.25 \%-100 \%$ & Very High \\
\hline
\end{tabular}

\section{RESULT AND DISCUSSION}

Here is the results of research conducted to determine the influence and how much the influence of Shopee In-Feed Native Video Ad "9.9 Super Shopping Day" on TikTok Application (X) on Audience Attitudes (Y). Variable X is measured using six elements of the stimuli of advertisement that stated by Rossiter \& Percy in (Jamil, A., \& Tafifah, 2019) which are: heard word, colour, music, seen word, picture, and movement have a significant influence on variable $\mathrm{Y}$, which is attitudes as evidenced by sub variable $\mathrm{Y}$, which is cognitive, affective and conative according to Schiffman et al. (2010) the discussion of each variable can be seen in explanation below:

Table 2. Recapitulation of Respondents' Responses to Advertising Variables (X)

\begin{tabular}{lc}
\hline \multicolumn{1}{c}{ Statement } & $\%$ \\
\hline 1.Heard Words & $74.2 \%$ \\
2.Colour & $72.5 \%$ \\
3.Music & $72.4 \%$ \\
4.Picture & $71.9 \%$ \\
5.Seen Words & $74.0 \%$ \\
6.Movement & $73.1 \%$ \\
\hline Total & $73.0 \%$ \\
\hline
\end{tabular}

In this study, heard words as one of the stimuli in advertising as a whole received a score of $74.2 \%$ which is on the high percentage category. Based on data collection result, the words heard on the advertisement can be heard clearly, e- 
asy to understand, and easy to remember. It can be concluded that the heard word in Shopee's advertisement on TikTok can make the message conveyed can be accepted and understood by the audience. It's related with the theory that stated by Rossiter \& Percy in (Jamil, A., \& Tafifah, 2019) that the words heard in the advertisement can make the audience understand the content of the message, and create an impression on the advertisement. This research also supports previous research conducted by Susanto (2014) which discusses the attitude of the Surabaya people on Teh Botol Sosro advertisement which shows that the heard word stimuli in the advertisement have a positive effect on attitudes.

Colour as one of the stimuli in advertising received a total score of $72.5 \%$ and can be categorized in high category. According to Rossiter and Percy in (Jamil and Tafifah 2019), the colors in advertisements must be matching, proportional, attractive, and lighting is one of the important things to be noticed. Based on the results above, it can be concluded that most respondents think that the colors used in the ad is attractive, proportional, match the brand colors, and has a good lighting system. Color grading is one of the important factors, as explained in previous research conducted by Nadhirshan \& Murwonugroho (2017) stated that color grading and shooting techniques became the attention of audience, so that the advertisements displayed were considered quite informative.

The next stimuli in advertising is music. In this research, music received a total score of $72.4 \%$ and was included in the high category. Based on the results above, the music used in the ad is attractive, easy to remember, and can affect audience's mood. So that, can attract audience attention, supporting the delivery of sales messages, and can be used to help the development process of a product's image. It's supports previous research conducted by Nadhirshan \& Murwonugroho (2017) which states that the music played in the advertisement can stimulate the audience's memory, both because of the music that is played throughout the advertisement and the music as a supporter element of the advertisement. In accordance with Rossiter and Percy in (Jamil and Tafifah 2019) statement that music in advertisement has several benefits such as attracting audience attention, supporting the delivery of sales messages, and can be used to help the development process of a product's image. The use of music in an advertisement can also affect the mood of the audience.

Picture stimuli received a total score of $71,9 \%$ and was included in the high category. According to Rossiter and Percy in (Jamil and Tafifah 2019), pictures are the images used in advertisements and seen by audiences when the advertisement takes place. Figure objects and model used in advertisements are two aspects included in the elements picture. Based on the results above, most of respondent think that the picture wich is Shopee's logo and talent is interesting and can be seen clearly. Previous research conducted by Susanto (2014) also shows the same result, where the picture element in the advertisement is responded positively by the audience, because picture is one of attractive element in advertisement.

In a research conducted by Setianing et al. (2019) stated that seen word is a functional element as an attraction in advertising. This is in accordance with the results of this study, where seen words received a total score of $74 \%$ and was included in the high category. According to Rossiter and Percy in (Jamil and Tafifah 2019), seen words are words that can be seen and read by the audience during the advertisement. The words that appear in an advertisement must be able to support the explanation of the message or benefits of a product described in an advertisement. The result of this research states most of respondent think that the seen word which is promotional information and caption used in the ad is can be seen clearly, easy to understand, and can support and deliver the message that want to conveyed by Shopee

The last stimuli is movement. Movement received a total score of $73,1 \%$ and was included in the high category. According to Rossiter and Percy in (Jamil and Tafifah 2019), movements in an advertisement can be used to support the explanation of the message that the advertisement wants to communicate to the public. Based on the results above, most of respondent think that the movement used in Shopee's InFeed Native Video Ad "9.9 Super Shopping Day" version on TikTok Application is suitable with the music, suitable with the promotional information, attractive and easy to remember so that can be used to support the explanation of the message that the advertisement wants to communicate to the public.

Tabel 3. Recapitulation of Respondents' Responses to Audience's Attitude Variables (Y)

\begin{tabular}{lc}
\hline \multicolumn{1}{c}{ Statement } & $\%$ \\
\hline 1.Cognitive Component & $68.2 \%$ \\
2.Affective Component & $67.2 \%$ \\
3.Conative Component & $66.2 \%$ \\
\hline Total & $\mathbf{7 3 , 0 \%}$ \\
\hline
\end{tabular}

In a previous research conducted by Launa et al. (2012) which discusses the effect of Axis advertising on audience awareness, the results showed that Axis advertisements on television had a medium impact on audience's cognitive respons and this advertisement had no significant impact on Axis brand awareness. Different to previous research, in this research cognitive aspect got a total score of $68.2 \%$ and is in the high category. Respondents states that they are aware, being attracted, can understand the message, interested to read the caption written in the ad, and they $\mathrm{n}$ remember the advertisment easily of Shopee's In-Feed Native Video Ad "9.9 Super Shopping Day" version when viewing content on TikTok. Based on result above, more of some respondent think that the ad can affect their cognition which is their knowledge, awareness and understanding. It related to Schiffman et al. (2010) which state that cognitive component is individual information and knowledge about objects or concepts. A person's cognition is knowledge and awareness obtained by the combination of direct experience with attitud- 
e-objects and related information from various sources.

The affective aspect in this study got a total score of $67,2 \%$ and is in the high category. Respondents states that they like the music, colour, movement and the message delivered in the ad. It related to Schiffman et al. (2010) that state that consumer feelings about a particular product or brand are an affective component of an attitude. These emotions and feelings are often treated as evaluative in nature, that capture a direct judgment to individuals perceive attitude objects as "favorable" or "unfavorable and "good "or" bad ". Research shows that this emotional state can improve or reinforcing positive or negative experiences and then memories of those experiences can influence what comes to mind and how the individual acts.

The conative aspect in this study got a total score of $66,4 \%$ and is in the high category. Respondent states that they do more action when the ad is played in their page. Some of them click "shop now" button, encouraged to watch longer, keep watching the ad until finish, and make a purchase on Shopee Application. Based on result above, more of some respondent think that the ad can influence their cognition which is their behaviour toward the advertisement. It supports previous research conducted by Ngangom (2020) which shows that based on the experience of participants, seeing advertisements on TikTok can influence their buying behavior. Participants in this study stated that they wanted to try a product because they often saw it on TikTok. It also related to Schiffman et al. (2010) that states conative is concerned with the possibility or tendency that individuals will take special actions or behave in certain ways related to the object of attitude. The conative component of attitude may include the behavior. In marketing and consumer research, the conative component is often treated as consumer's intention to buy. Buyer intention scale used to assess the likelihood of a consumer buying a product or behaving in a certain way.

Table 4. Coefficient of Shopee's In Feed Native Video Ad on Audience Attitude

\begin{tabular}{c|c|c|c}
\hline \multicolumn{1}{c|}{ Model } & $\begin{array}{c}\text { Unstandarized } \\
\text { Coefficient }\end{array}$ & \multirow{2}{*}{$\mathrm{t}$} & Sig. \\
\cline { 2 - 3 } & \multicolumn{2}{|c|}{$\mathrm{B}$} & \\
\hline $\begin{array}{l}\text { Shopee's In- } \\
\text { feed }\end{array}$ & 0.701 & 23.742 & 0.000 \\
Advertisement & & & \\
\hline
\end{tabular}

The $\mathrm{t}$ value in this study is 23.742 from a significance value of 0.000 . If compared with the table value of 1.96 and a significance value of 0.005 , the researchers found a significant influence given by Shopee's In Feed Native Ad "9.9 Super Shopping Day" on TikTok Application to the audience's attitude. Based on the beta coefficient value, it is known that the value is 0.701 , which means that if the value of shopee in-feed native video ads increases by 1 unit, then the value of audience attitude will increase by 0.701 or $70 \%$. In a previous study entitled "The Effect of Pop-up Advertising on Bukalapak's Hero Version on Audience Atti- tudes" that conducted by Ammarie \& Nurfebiaraning (2019), the results showed that there was a significant effect between pop-up ads on YouTube on attitudes towards audinece attitudes in cognitive, affective and conative aspect. This study supports previous research where audiovisual advertisements have a significant and positive effect on audience attitudes in terms of cognitive, affective and conative. The difference is, previous research used YouTube media and examined the influence of pop-up ads on audience attitudes. Meanwhile, this study uses TikTok as a merketing communication tool and examines the influence of in-feed native video ads towards audience attitudes. As a result, TikTok as a new application, was able to have a high influence on the audience in cognitive, conative, and affective aspects as produced by pop-up ads on YouTube which in fact have long been used by e-commerce companies to advertise. Its related to Fishbein \& Azjen (1975) that state stimuli such as advertisements from certain brands, affect the consumer belief system which then influences and causes consumers to develop certain attitudes towards the advertised brands. The attitudes that consumers have with regard to brands have an impact on consumers' intentions to buy the brands offered.

Table 5. Summary Table of Shopee's In Feed Native Video Ad on Audience Attitude

\begin{tabular}{c|c}
\hline Model & R Square \\
\hline $\begin{array}{c}\text { Shopee's In-Feed Native } \\
\text { Advertisement }\end{array}$ & 0.586 \\
\hline
\end{tabular}

Based on the calculation of the formula above, the coefficient of determination is $58,6 \%$. This shows that the value of the influence of the Advertising variable $(\mathrm{X})$ on the Audience Attitude variable (Y) is 58,6\%. Shopee itself is the most popular e-commerce company in Indonesia, so it has a very high popularity. Therefore, Shopee can plan and execute a good and various marketing strategy. Because the influence of advertising on audience attitudes does not only depend on advertising, the use of the TikTok application as one of the advertising media used by Shopee which gives results of $58.6 \%$ on audience attitudes has a high influence. While the remaining $41,4 \%$ is influenced by other factors not examined in this study and can be investigated by further research.

The results of this study support previous research conducted by Mou (2020), that state the use of TikTok as a marketing communication media is becoming increasingly diverse and has a good target. Targets are achieved quickly and precisely due to a very supportive brand ecosystem. Brands have many options when it comes to investing in advertising as KOL members grow. In 2019, the brands invested in TikTok marketing are getting more diversified.

\section{CONCLUSION}

Based on the results of the research that has been done, several conclusions are drawn to answer the identification of the problems posed in this study based on the data analysis that has been stated in the previous chapter. There is an influence between Shopee's In-Feed Native Video Ad on TikTok Appli- 
cation toward Audience Attitude. Because, based on the results of the $t$ test which shows that the advertising variable (X) has a greater value of $\mathrm{t}$ count than $\mathrm{t}$ table, then $\mathrm{H} 0$ is rejected and $\mathrm{H} 1$ is accepted. It's means that the advertising variable $(\mathrm{X})$ has a significant influence on the dependent variable which is the audience's attitude (Y). This shows that all stimuli in advertisements, which are heard word, color, music, picture, seen word, and movement simultaneously affect the attitudes of the audience which are followers of @ shopee_id official account on TikTok. The attitude of the audience in this study was measured using cognitive, affective, and conative aspects.

The magnitude of the influence of the Shopee's In-Feed Native Video Ad on TikTok Application toward Audience Attitude can be seen in the analysis test results of the coefficient of determination in which the $\mathrm{R}$ square is obtained by $58.6 \%$. This shows that the magnitude of the influence of the Advertisement variable (X) on the Audience Attitude variable $(\mathrm{Y})$ is $58.6 \%$. While the remaining $41,4 \%$ is influenced by other factors not examined in this study.

\section{ACKNOWLEDGEMENT}

Praise to Allah SWT, because with His blessing and guidance, the reseacher can complete this research project. Thanks to beloved family and friends who always pray, give love, and encourage all the time. Big thanks to Kanal Journal of Muhammadiyah Sidoarjo University which has provided the opportunity for researchers to accommodate this scientific paper.

\section{REFERENCES}

Aliaga, M., \& Gunderson, B. (2002). Interactive Statistic. Prentice Hall.

Ammarie, R. H., \& Nurfebiaraning, S. (2019). Pengaruh Iklan Pop-Up Bukalapak Versi Pahlawan Pada Youtube Terhadap Sikap Khalayak. Jurnal Manajemen Komunikasi. https://doi.org/10.24198/jmk.v2i2.12871

Annur, C. M. (2020). TikTok Telah Diunduh Lebih dari 2 Miliar Kali di Dunia. Https://Databoks.Katadata.Co.Id/. https://databoks.katadata.co.id/datapublish/2020/09/21/tiktok-telahdiunduh-lebih-dari-2-miliar-kali-di-dunia.

Christy, F. E. (2020). Top 10 E-commerce di Indonesia Kuartal I 2020. Tempo.Co. https://data.tempo.co/data/907/top-10-e-commerce-diindonesia-kuartal-i-2020.

Darmatama, M., \& Erdiansyah, R. (2021). The Influence of Advertising in Tiktok Social Media and Beauty Product Image on Consumer Purchase Decisions. International Conference on Economics, Business, Social, and Humanities (ICEBSH 2021), 570. https://doi.org/http://dx.doi.org/10.2991/assehr.k.210805.140.

Evans, D. (2009). The Online Advertising Agency: Economic,Evolution, and Privacy. Journal of Economic Perspective, 23, 37-60. https://doi.org/10.1257/jep.23.3.37.

Fishbein, M., \& Azjen, I. (1975). Belief,Attitude, Intention, and Behaviour. An Introduction to Theory and Research. Addison-Wesley Publishing Company.

Jamil, A., \& Tafifah, R. (2019). Advertisement and Spirit of Nationality. https://doi.org/https://doi.org/10.29032/ijhsss.v5.i2.2019.67-83.

Kotler, Philip, dan Keller, K. L. (2016). Marketing Management (15th Global Edition). Pearson Education Limited.

Launa, L., Arifin, H. S., \& Widyowati, W. (2012). Pengaruh Terpaan Iklan Televisi Axis Versi "Pake Sedikit Dijamin Gratisannya Banyak" Terhadap Brand Awareness Di Kalanagan Mahasiswa Bandung. Students E-Journal.

Lifepal. (2020). Jadi E-commerce Terpopuler, Ini 5 Strategi Shopee yang Bisa Ditiru. Https://Lifepal.Co.Id/. https://lifepal.co.id/media/mencontek-5- strategi-shopee-buat-mendongkrak-bisnis/.

Mou, J. B. (2020). Study on social media marketing campaign strategy - TikTok and Instagram. Massachusetts Institute of Technology.

Nadhirshan, K., \& Murwonugroho, W. (2017). Analisis Pengaruh Iklan Google App : Cari Lagu \# Selalutaumusik Terhadap Respon Pada Sasaran. Seminar Nasional Cendekiawan.

Ngangom, M. (2020). How TikTok Has Impacted Generation Z's Buying Behaviour and Their Relationship With Brands? The Students Of The British Journal of International Studies. https://esource.dbs.ie/bitstream/handle/10788/4116/msc_nganom_m_202 0 .pdf? sequence $=1$ \&isAllowed $=y$.

Nur Ratri, A. (2021). Pengaruh Terpaan Iklan pada Konten Video dengan Hashtag \#shopeehaul di Media Sosial TikTok terhadap Perilaku Konsumtif Generasi Millenial. Universitas Pelita Harapan. http://repository.uph.edu/17062/.

Rohimah, A. (2019). Era Digitalisasi Media Pemasaran Online dalam Gugurnya Pasar Ritel Konvensional. KANAL: Jurnal Ilmu Komunikasi. https://doi.org/10.21070/kanal.v6i2.1931

Schiffman, L. G., Kanuk, L. L., \& Wisenblit, J. (2010). Consumer Behavior. Global Edition. Pearson Higher Education, London.

Setianing, A., Hijriah, L., \& Dwivayani, K. D. (2019). Persepsi Remaja Putri Terhadap Iklan Clean and Clear Versi 1000 Suku Indonesia, Warna Kulit Berbeda di YouTube. Dunia Komunikasi- Jurnal Ilmu Komunikasi Universitas Mulawarman, 7. https://ejournal.ilkom.fisipunmul.ac.id/site/?p=3954.

Susanto, Y. (2014). Sikap Masyarakat Surabaya Pada Iklan Televisi Teh Botol Sosro Versi “PET 450ML." Jurnal E-Komunikasi Universitas Negeri Petra, $2 . \quad$ http://publication.petra.ac.id/index.php/ilmukomunikasi/article/view/3780.

Conflict of Interest Statement: The authors declare that the research was conducted in the absence of any commercial or financial relationships that could be construed as a potential conflict of interest.

Copyright $\odot 2021$ Amrudhia and Nurfebiaraning. This is an open-access article distributed under the terms of the Creative Commons Attribution License (CC BY). The use, distribution or reproduction in other forums is permitted, provided the original author(s) and the copyright owner(s) are credited and that the original publication in this journal is cited, in accordance with accepted academic practice. No use, distribution or reproduction is permitted which does not comply with these terms. 